University of Nebraska - Lincoln

DigitalCommons@University of Nebraska - Lincoln

1983

\title{
Spatial and Temporal Variations in Long-Term Normal Percent Possible Solar Radiation Levels in the United States
}

\author{
Robert C. Balling \\ University of Nebraska-Lincoln \\ Randall S. Cerveny \\ University of Nebraska-Lincoln
}

Follow this and additional works at: https://digitalcommons.unl.edu/natrespapers

Part of the Natural Resources and Conservation Commons, Natural Resources Management and Policy Commons, and the Other Environmental Sciences Commons

Balling, Robert C. and Cerveny, Randall S., "Spatial and Temporal Variations in Long-Term Normal Percent Possible Solar Radiation Levels in the United States" (1983). Papers in Natural Resources. 1197. https://digitalcommons.unl.edu/natrespapers/1197

This Article is brought to you for free and open access by the Natural Resources, School of at DigitalCommons@University of Nebraska - Lincoln. It has been accepted for inclusion in Papers in Natural Resources by an authorized administrator of DigitalCommons@University of Nebraska - Lincoln. 


\title{
Spatial and Temporal Variations in Long-Term Normal Percent Possible Solar Radiation Levels in the United States
}

\author{
Robert C. Balling, JR. AND Randall S. CeRveny \\ Climatology Program, Department of Geography, University of Nebraska, Lincoln, NE 68588
}

(Manuscript received 7 March 1983, in final form 23 June 1983)

\section{ABSTRACT}

\begin{abstract}
The purpose of this study was to analyze the time and space variations in long-term monthly-averaged daily percent possible solar radiation levels in the United States. Both principal components analysis and harmonic analysis were used to identify the influences of various synoptic-scale climatological phenomena on solar radiation receipt. Generally, an annual cycle was found with maximum percent possible radiation levels occurring in July. In many regions the temporal variance structure deviated from this general annual cycle. The results, which are useful in both theoretical and practical studies, lead to a better understanding of the climatology of solar radiation in the United States.
\end{abstract}

\section{Introduction}

In a recent study, Balling (1983) utilized harmonic analysis effectively to define and explain temporal and spatial patterns associated with long-term monthly insolation levels in the United States. Because of the marked annual cycle found in the march of monthly solar radiation levels in midlatitudes, the first harmonic explained more than $98 \%$ of the variance in monthly insolation levels for 221 stations in the United States. The amplitudes, explained variances and phase angles associated with the first two harmonics illustrated the magnitude of the influence of season, terrain and general circulation features on long-term average irradiance values.

In many theoretical and applied studies, researchers are more concerned with the percentage of possible solar radiation received at the earth's surface (Liu and Jordan, 1960; Knapp et al., 1980). These percent possible radiation levels are independent of the strong annual cycle in solar radiation values that is forced by basic earth-sun geometry. In this paper, the analyses of the time and space variations in percent possible solar radiation levels magnify and clarify the effects of various climatological controls on solar receipt.

\section{Insolation data}

A $221 \times 12$ matrix was constructed containing monthly estimates of percent possible solar radiation for 221 stations (Figs. 2-12) in the conterminous United States. The values of percent possible radiation for all stations were extracted from the recently published Insolation Data Manual (Knapp et al., 1980).
These data were generated from regression equations established at the 26 SOLMET (SOLar METeorological) stations that accurately estimate hourly and daily insolation levels from the commonly observed surface meteorological variables. The long-term (24-25 years) monthly-averaged daily levels of global solar radiation $Q$ were divided by monthly extraterrestrial solar radiation $Q_{0}$ to yield the percent possible radiation parameter $K_{T}$. These monthly $K_{T}$ values represent the fraction of horizontal solar radiation transmitted through the atmosphere reaching the surface. Although $K_{T}$ has been called the cloudiness index (Liu and Jordan, 1960; Knapp et al., 1980), $K_{T}$ displays the effects of elevation and other atmospheric conditions on insolation. Knapp et al. (1980) stated that their published $K_{T}$ values are among the best estimates available at this time.

\section{Climatological overview}

Daily and monthly values of $K_{T}$ have long been used in attempts to relate the percentage of possible sunshine at a station to insolation levels (Kimball, 1919; Fritz and MacDonald, 1949; Black et al., 1954; Hamon et al., 1954). The strong statistical relationships, both linear and nonlinear, between $K_{T}$ and sunshine suggest that their basic spatial and temporal patterns could be interchanged with little loss of accuracy.

For the United States as a whole, mean values of $K_{T}$ continued to show a strong annual cycle ranging from 57.9 to $43.9 \%$ in July and December, respectively (Table 1). In accordance with the suggestions of Bennett (1975), the median $(M d)$ is presented, and it also displayed a strong annual cycle. Absolute spatial variability, as described by the standard deviation 
TABLE 1. Selected descriptive statistics for percent possible radiation data.

\begin{tabular}{lcccccc}
\hline \hline Month & $K_{T}$ & $M d$ & $\sigma$ & $C V$ & $z^{*}$ & \multicolumn{1}{c}{$z^{*}$} \\
\hline Jan & 44.8 & 43.7 & 9.1 & 20.3 & 1.8 & -1.5 \\
Feb & 48.8 & 48.1 & 8.3 & 16.9 & 2.2 & -1.3 \\
Mar & 51.3 & 49.7 & 8.1 & 15.8 & 3.1 & -1.4 \\
Apr & 53.1 & 51.0 & 8.0 & 15.0 & 5.2 & -0.4 \\
May & 54.6 & 52.6 & 7.8 & 14.3 & 6.2 & 0.5 \\
Jun & 56.6 & 54.9 & 8.2 & 14.4 & 5.1 & -1.0 \\
Jul & 57.9 & 57.2 & 8.1 & 14.1 & 2.7 & -2.9 \\
Aug & 57.4 & 56.7 & 8.0 & 14.0 & 3.0 & -2.4 \\
Sep & 56.2 & 54.3 & 8.4 & 14.9 & 4.3 & -1.9 \\
Oct & 55.2 & 54.5 & 8.1 & 14.6 & 2.4 & -1.6 \\
Nov & 48.3 & 48.9 & 9.6 & 19.8 & 0.4 & -2.1 \\
Dec & 43.9 & 43.8 & 9.8 & 22.4 & 1.0 & -2.2 \\
\hline
\end{tabular}

* Absolute values greater than 1.96 are significant at the 0.95 confidence level.

$(\sigma)$ displays a weaker annual cycle with highest values found in the low-sun months. The coefficient of variation showed a much stronger annual cycle with lowest and highest values found in August and December, respectively. Standardized coefficients of skewness $\left(z_{1}\right)$ and kurtosis $\left(z_{2}\right)$ calculated as:

$$
\begin{gathered}
z_{1}=\left\{\frac{\left[\sum_{i=1}^{N}\left(K_{T_{i}}-\bar{K}_{T}\right)^{3} / N\right]}{\left[\sum_{i=1}^{N}\left(K_{T_{i}}-\bar{K}_{T}\right)^{2} / N\right]^{3 / 2}}\right\}(6 / N)^{-1 / 2}, \\
z_{2}=\left\langle\left\{\frac{\left[\sum_{i=1}^{N}\left(K_{T_{i}}-\bar{K}_{T}\right)^{4} / N\right]}{\left[\sum_{i=1}^{N}\left(K_{T_{i}}-\bar{K}_{T}\right)^{2} / N\right]^{2}}\right\}-3\right\rangle \\
\times(24 / N)^{-1 / 2}
\end{gathered}
$$

demonstrated that the spatial arrays of monthly $K_{T}$ data were generally not normally distributed (Siegel, 1956; Keeping, 1962; Granger, 1979). From February to October, the distributions were significantly positively skewed, suggesting that a few stations with especially large values of $K_{T}$ produced a monthly mean that was greater than the mode. July, August, November, and December all displayed spatial distributions with significant negative kurtosis levels, suggesting that a linear, continuous spatial gradient existed with little to no central tendency (Fig. 1). Only the month of January had a spatial distribution that did not vary significantly from the normal curve.

While these distributions may not be normally distributed, they were certainly associated with coherent and meaningful spatial patterns. Mean annual levels of percent possible radiation (Fig. 2) ranged from $71.6 \%$ at Tonopah, Nevada to $38.7 \%$ at Binghamton, New York. High values of $K_{T}$ dominated the Southwest, while low values characterized the Northwest and much of the northeastern quarter of the United

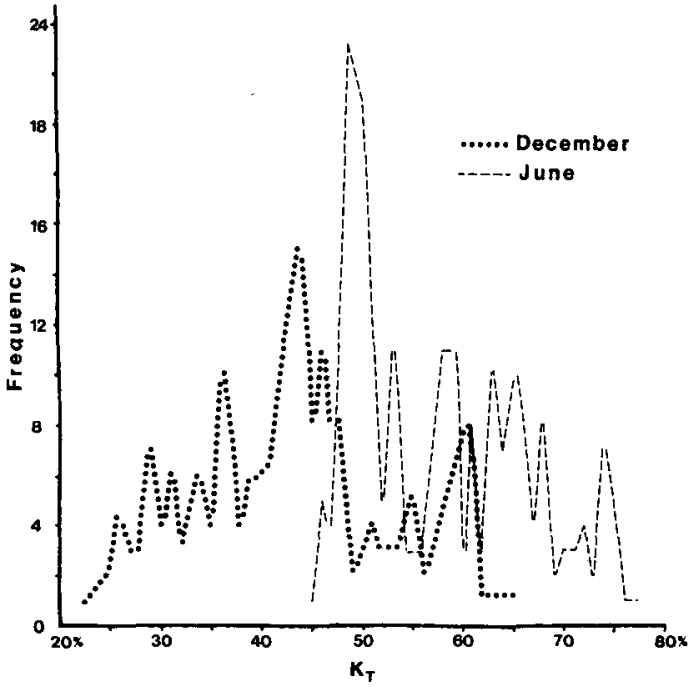

FIG. 1. Representative spatial frequency distributions (June and December) of $K_{T}$.

States. The spatial pattern of annual $K_{T}$ levels was nearly identical to the pattern displayed on a map published in 1920 of the percentage of possible sunshine over the United States (Kincer, 1920).

The intermonthly variance $\sigma^{2}$ associated with the station means showed a general north-to-south gradient (Fig. 3) with values ranging from $2.8(\%)^{2}$ at Tucumcari, New Mexico to $151.5(\%)^{2}$ at Medford, Oregon. The largest variance levels were found in the Northwest, central California, and the northern Great Lakes area. A similar spatial pattern is displayed on a map of the coefficient of variation of $K_{T}$ (Fig. 4).

A O-mode factor analysis (Willmott, 1978; Balling, 1984) of the $221 \times 12$ matrix of $K_{T}$ values suggested that two spatial patterns underlie the variance structure in the data. One orthogonally rotated pattern explained $88.1 \%$ of the variance in the data and displayed the highest loading $(0.93)$ with the array of December $K_{T}$ values. The spatial pattern for the December values

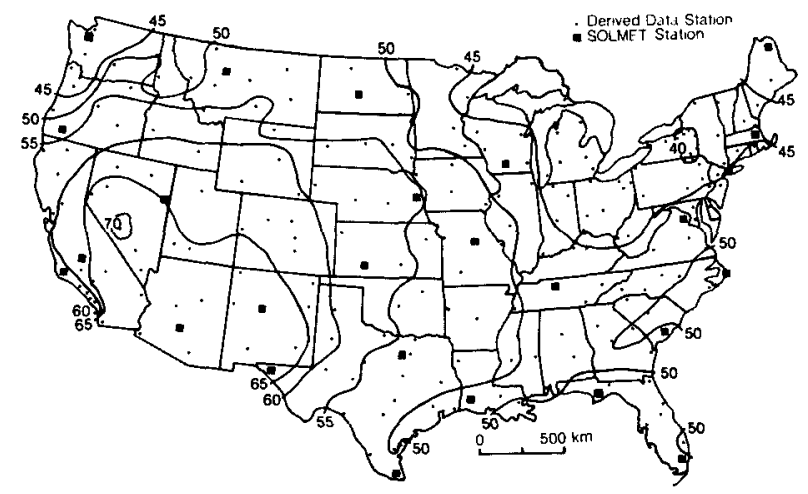

FIG. 2. Mean annual $K_{T}$. 


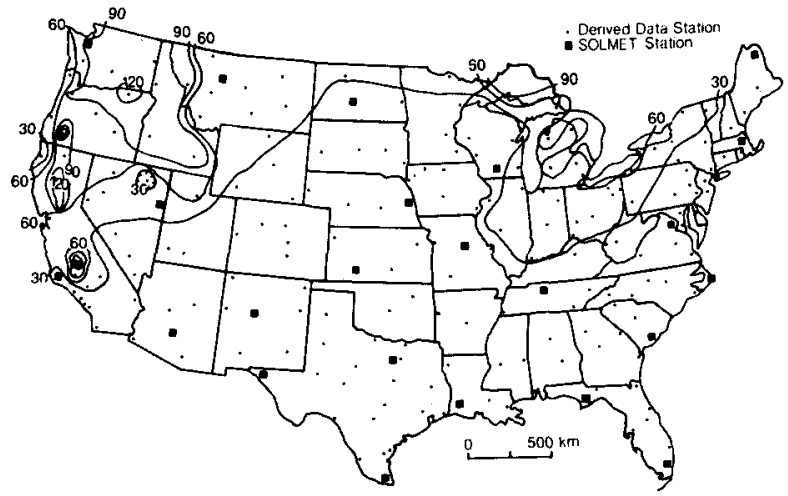

FIG. 3. Intermonthly variance of $K_{T}$.

(Fig. 5) is similar to the plot for the mean annual levels (Fig. 2). A second spatial pattern revealed by the factor analysis explained $8.3 \%$ of the total variance in the $K_{T}$ matrix. July displayed the highest loading $(0.94)$ with the variance structure depicted by the second factor. In that month, gradients extended away from the high values that dominated the interior portion of the western United States (Fig. 6). Clear skies associated with a more northern and eastern position of the surface North Pacific high pressure cell were strongly reflected in the July pattern. However, only a more detailed analysis of the annual march of $K_{T}$ for each station could effectively reveal the impact of various synopticscale climatological features on the radiation values.

\section{Harmonic analysis}

Following its development by Fourier (1822), harmonic analysis has been repeatedly used in the study of meteorological and climatological phenomena for over 150 years (e.g., Bessel, 1828; Whipple, 1917; von Hann, 1917; Brooks and Mirrlees, 1930; Conrad, 1938; Prescott, 1943; Reynolds, 1955; Craddock, 1956; Horn and Bryson, 1960; Sabbagh and Bryson, 1962; Fitzpatrick et al., 1966). Harmonic analysis allows each

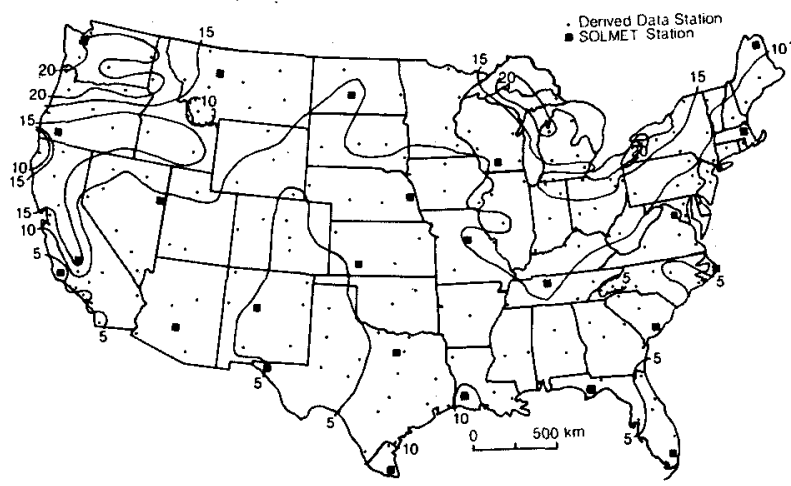

FIG. 4. Coefficient of variation of $K_{T}$.

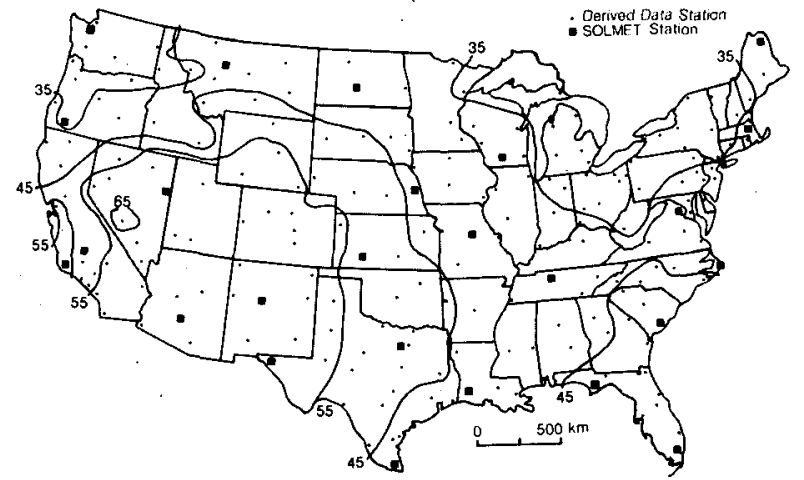

FIG. 5. December values of $K_{T}$.

station's annual "curve" of $K_{T}$ values to be represented as statistically independent components that may be separately mapped for analysis. The general form of harmonic analysis is:

$$
\hat{K}_{T}=\bar{K}_{T}+\sum_{r=1}^{n / 2} A_{r} \cos \left(r \theta-\Phi_{r}\right)
$$

where $\hat{K}_{T}$ is the estimated monthly value of $K_{T}, \bar{K}_{T}$ is the mean annual $K_{T}$ level, $n$ the number of observations at each station (equal to 12 months), $A_{r}$ the amplitude of each harmonic wave of frequency $r, \theta$ equals $2 \pi x$ l $p$ for $x$ the time in months, and $p$ the fundamental period equal to 12 months, and $\Phi_{r}$ is the phase angle of the fitted wave. The first harmonic produces a fit with one maximum and one minimum spaced six months apart and thus describes annual tendencies in the march of the $K_{T}$ values. The semiannual variance structures are displayed by the second harmonic which has two equally spaced maxima and minima. While up to six harmonics may be required to account for all variance in the array of $K_{T}$ values at each station, the higher harmonics often fail to account for statistically significant (Brooks and Carruthers, 1953) portions of total variance. Spatial patterns in the amplitudes, explained variances, and phase angles may be

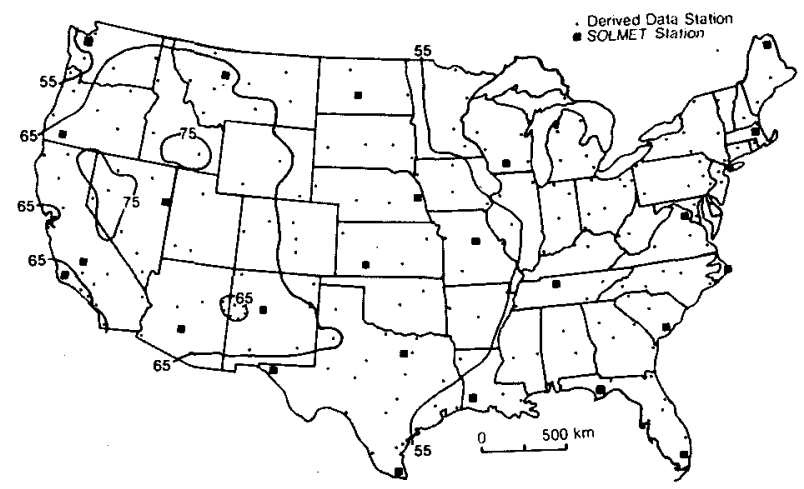

FIG. 6. July values of $K_{T}$. 
useful in evaluating influences of elevation and various synoptic-scale phenomena on insolation at the surface of the earth.

\section{First harmonic}

The pattern of first harmonic amplitudes (Fig. 7) resembled the map of intermonthly variance levels (Fig. 3). The strength of the relationship is reflected in the high map-pattern correlation (Blasing, 1975) of 0.96 that exists between the two maps.

The total portion of variance across the United States explained by the first harmonic, defined explicitly as

$$
V_{1}=\frac{\sum_{i=1}^{221} A_{1_{i}}^{2}}{\sum_{i=1}^{221} 2 \sigma_{i}^{2}}
$$

equaled $83.9 \%$ while the mean explained variance level for the 221 stations equaled $75.5 \%$. The explained variances ranged from a low of $8.5 \%$ at Point Mugu, California, to a maximum of $95.2 \%$ at nearby Sunnyvale, California (Fig. 8). The values tended to be low along portions of the California coast, throughout the Southwest and Front Range area, and across much of the southeastern section of the United States.

The map of first harmonic phase angles (Fig. 9) is particularly beneficial in identifying the nature of the annual cycle in the $K_{T}$ data. In much of the United States, maximum values in the annual cycle occurred in the summer months, often in July. During this time, cyclonic storm passages are at a minimum, the storminess of June has subsided (Markham, 1970), and a large section of the interior United States is affected by the midtropospheric anticyclonic cell (Wexler and Namais, 1938; Namais, 1972). Maximum values in the annual cycle of $K_{T}$ tended to occur in late spring and early summer in Point Mugu, the Southwest, and northern Maine. Maximum values occurred in late winter and early spring in peninsula

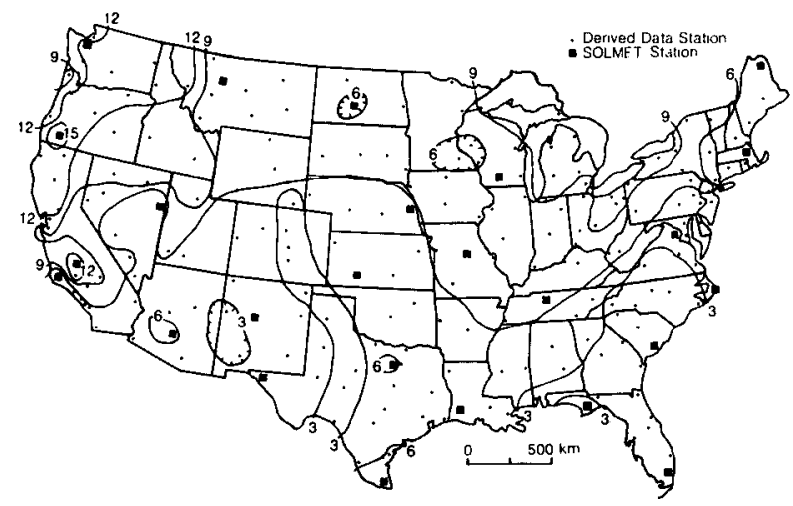

FIG. 7. First harmonic amplitudes.

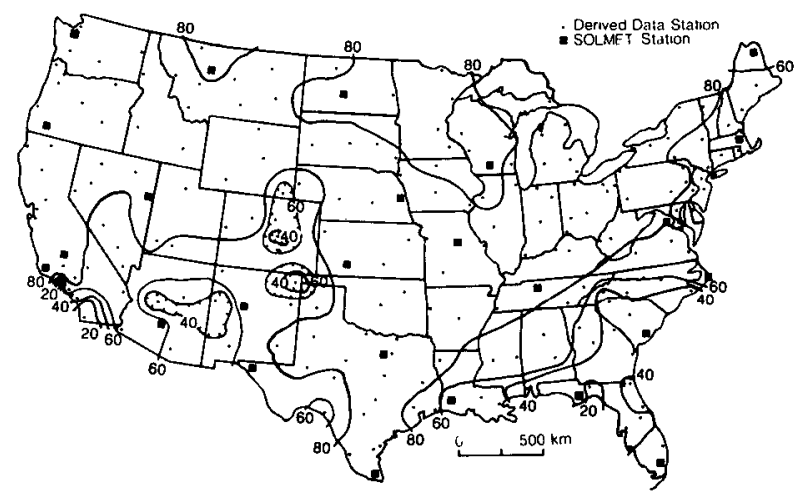

FiG. 8. First harmonic explained variances.

Florida, while in the Front Range area they occurred during the early fall period.

The early maximum found at Point Mugu, California appears to be related to the unusual local climates of the area. Throughout June and July, the low stratus deck that results from strong advection over the particularly cold ocean surface apparently acts dramatically to reduce the potential insolation levels. The Southwest displayed an early maximum due to the pronounced increase in atmospheric moisture and afternoon cloudiness that characterizes the later summer months (Bryson and Lowry, 1955; Horn et al., 1957; Hales, 1974). During this "monsoon" period, the surface North Pacific High moves into its northerly position, and moisture is freely advected into the Southwest from the Pacific and/or Gulf of Mexico (Hales, 1974). The especially clear and dry conditions in the region before this period act to maintain high levels of $K_{T}$.

The early maximum found in the annual cycle of $K_{T}$ in northern Maine appears to be related to a sharp decrease in potential radiation in November and December. Strong minimum values occurring in these months characterized by large well-developed cyclonic storm passages shift the first harmonic fits to positions displaying annual maxima in the early

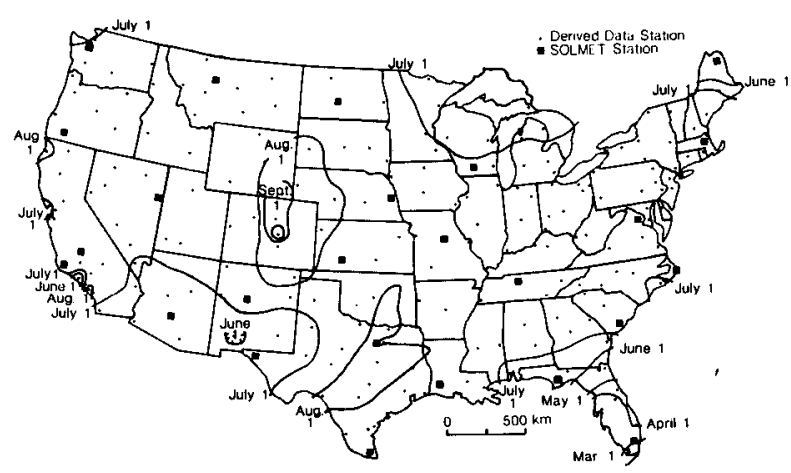

FIG. 9. First harmonic phase angles. 
summer months. The raw data show no real propensity for such early summer maximum, but rather a strong tendency for a late fall or early winter minimum. The springtime maxima found throughout the Florida peninsula are linked to the clear conditions associated with a general lack of cyclonic passages or convective activity in the late winter and early spring season.

The only area with especially late maximum values in the annual cycle of percent possible radiation was found along the Front Range of the Rockies. Maxima as late as October in Colorado Springs, Colorado are associated with decreased convection and little cyclonic activity in the early fall months. Throughout the summer, afternoon thunderstorms (Wallace, 1975) caused by intense heating of the slopes of the Rockies diminishes radiation receipt thereby forcing maximum $K_{T}$ levels to occur later in the year. While the first harmonic allowed for an interpretation of annual cycles in the data, significant information regarding semidiurnal cycles may be gleaned from analysis of the second harmonic fits.

\section{Second harmonic}

The second harmonic explained $10.9 \%$ of the total variance in the United States; however, the mean portion of variance explained at each station equaled $15.8 \%$. This statistic ranged from $0.3 \%$ at Wichita Falls, Texas to $78.1 \%$ at Tallahassee, Florida (Fig. 10). The second harmonic appeared to be particularly important in explaining variance on the southern California coast, in the Southwest, Southeast, and northern Maine.

The phase angles associated with the more important second harmonic fits (Fig. 11) generally reflected the circulation features described earlier. Along the California coast where the second harmonic explained more than $50 \%$ of the intermonthly variance at Point Mugu and San Diego, phase angles showed semiannual maxima occurring in March and September. During these equinox months, the North Pacific high pressure cell is in a position favorable for clear skies along the

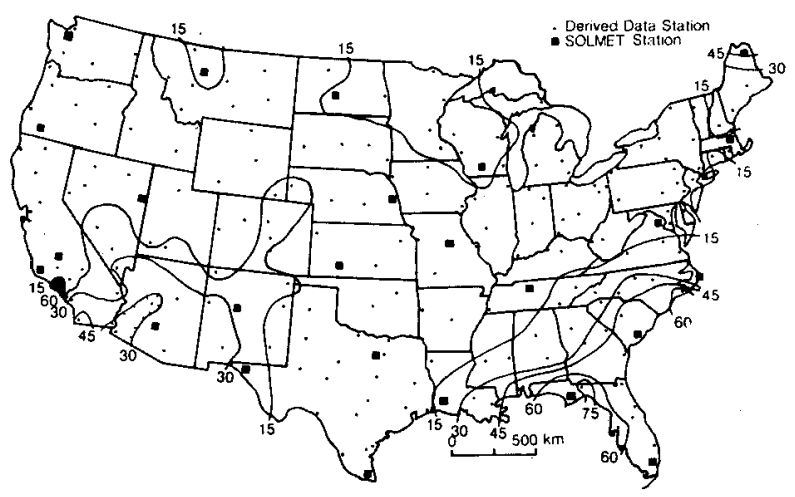

FIG. 10. Second harmonic explained variances.

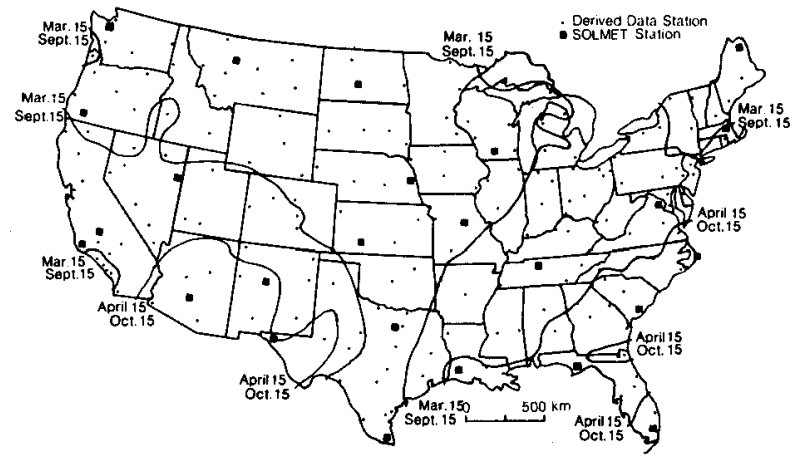

Fig. 11. Second harmonic phase angles.

coast. In June and December, heavy fog and increased cyclonic activity, respectively, act to create minima levels of $K_{T}$.

The Southwest displayed maxima in April and October, with corresponding minima in January and July. Wintertime storms in January and convective systems in July effectively diminish percent possible radiation levels during portions of the year. The pattern is reproduced in the Gulf Coast area and peninsula Florida where April and October were also identified as months with maximum $K_{T}$ levels.

In northern New England, and especially in Caribou, Maine, phase angles for the second harmonic suggested maxima in late February-early March and late August-early September, minima in NovemberDecember and May-June. These features generally are representative of the annual curve of $K_{T}$ values. The highest monthly $K_{T}$ for Caribou (52.4\%) occurs in March when storm tracks are farther south, moisture levels are low, and northwesterly surface flow prevails. The primary minima in November $(32.3 \%)$ and the secondary minima in May $(45.7 \%)$ appear to be related to the passage of numerous cyclonic storms. The second harmonic's representation of a secondary maxima in late August-early September is somewhat fictitious; the actual secondary maxima occurs in July and August when $K_{T}$ values are $49.2 \%$ and $48.0 \%$, respectively.

When combined, the first two harmonics explained $94.8 \%$ of the nationwide variance in the monthly levels of $K_{T}$. A plot of the explained variance data (Fig. 12) suggested that while most areas are well depicted by two harmonics, some locations are characterized by important and significant higher harmonics.

\section{Higher harmonics}

The third harmonic, characterized by peaks spaced four months apart, or maxima and minima two months apart, explained only $3.2 \%$ of the nationwide variance in $K_{T}$ levels. However, it accounted for more than $25 \%$ of the intermonthly variance at four widely 


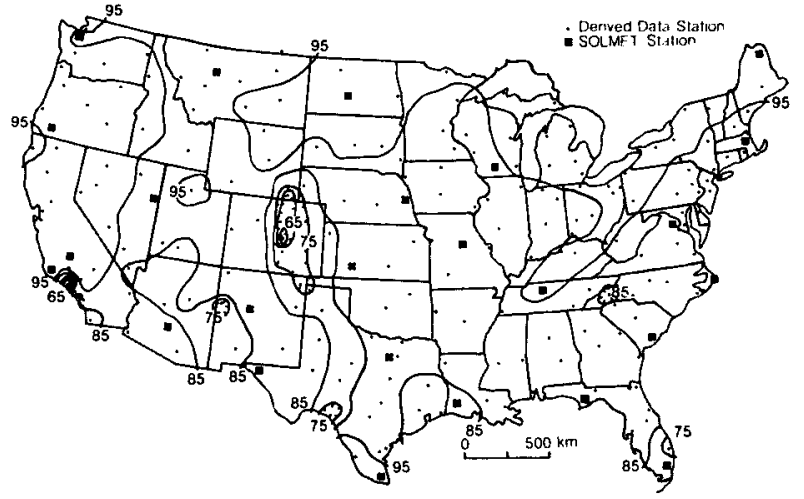

FIG. 12. Portion of variance explained by the first two harmonics.

separated stations. At Point Mugu, California, 36.3\% of the variance was explained by the third harmonic. Here April and August displayed strong peaks in the $K_{T}$ profile, while June had one of the year's lowest values. The April maximum is associated with a position of the North Pacific High that is favorable for clearing in southern California. As the high shifts northward and eastward in early summer, especially cold sea surface temperatures characterize offshore waters near Point Mugu, and low stratus and fog results. By August, the sharp contrast between sea and air temperatures has diminished, and the general clearing results in high levels of $K_{T}$.

Colorado Springs, Colorado had a third harmonic fit explaining $27.6 \%$ of the total variance, and several nearby Front Range stations also had nearly $20 \%$ of their variance accounted for by the third harmonic. The raw data at these locations indicated a strong maximum in September and October, with a strong minimum in July and August. The observed pattern is related to the summertime convective processes described earlier.

The third harmonic explained $26.6 \%$ of the variance in Del Rio, Texas, and the phase angle indicated maxima in March, July, and November. And indeed, the raw data clearly displayed a trimodel distribution. In March and November, convection and cyclonic activity are low in southwestern Texas, and in July, the midtropospheric anticyclone circulation dominates the flow pattern. The relatively cloud free conditions in these three equally spaced months allows peaks in the $K_{T}$ to be well depicted by the third harmonic fit.

Similarly, West Palm Beach, Florida also displayed a pronounced trimodel distribution, and accordingly, the third harmonic accounted for $30.4 \%$ of the total intermonthly variance. Distinctive peaks occurred in early portions of April, August and December. The peaks in early April and December are associated with a quiet weather pattern of little convective or frontal activity. The peak in early August is forced by the most easterly penetration of the Bermuda High into the United States. The effects of convective activity and tropical storms can be seen in especially strong minima occurring in early June and October, respectively.

The fourth harmonic was generally unimportant, accounting for only $0.8 \%$ of the nationwide variance. The highest explained variance level for any station was $8.8 \%$, found at Clayton, New Mexico. Highest explained variance levels were found in the southern Front Range area where a complex pattern of phase angles was uncovered. Topographic influences may allow small changes in the general flow pattern to magnify changes in cloud cover, turbidity, and sunshine. In northeastern Florida, where stations displayed a sharp peak in April and May, and a deep minimum in June, the fourth harmonic accounted for approximately $6 \%$ of the intermonthly variance. No other spatially homogeneous areas were found in the patterns of the higher harmonics.

\section{Conclusions}

Both factor and harmonic analysis were used to study the spatial and temporal dimensions of long-term monthly-averaged percent possible solar radiation levels $K_{T}$ in the conterminous United States. Factor analysis showed that the spatial structure of month-tomonth patterns are remarkably coherent through the year. However, harmonic analysis of individual stations revealed important features in the annual march of percent possible solar radiation.

Nationwide, over $80 \%$ of the total variance in $K_{T}$ levels was explained by the first harmonic fit. Maximum values in the annual cycle generally occurred in July when high pressure cells penetrate the United States along both coasts. In a variety of regions, the variance structure deviated from this general pattern. Analysis of phase angles, amplitudes, and explained variance levels for up to four harmonics allowed the spatial and temporal influences of elevation, season, and synoptic and circulation features to be precisely identified.

Acknowledgments. The authors are sincerely appreciative of the constructive comments, criticisms, and suggestions of two anonymous reviewers.

\section{REFERENCES}

Balling, R. C., Jr., 1983; Harmonic analysis of monthly insolation levels in the United States. Sol. Energy, 31, 293-298.

- 1984: Classification in climatology, Spatial Statistics and Models, G. L. Gaile and C. J. Willmott, Eds., Reidel, 81-108.

Bennett, I., 1975: Variation of daily solar radiation in North America. Arch. Meteor. Geophys. Bioklim., B23, 31-57.

Bessel, F. W., 1828: On the determination of the law of physical phenomenon translated in Brit. Quart. Weather Report, 1870 (Appendix IV).

Black, J. N., C. W. Boynthon and J. A. Prescott, 1954: Solar radiation 
and the duration of sunshine. Quart. J. Roy. Meteor. Soc., 80, 231-235.

Blasing, T. J., 1975: A comparison of map-pattern correlation and principal component eigenvector methods for analyzing climatic anomaly patterns. Preprints Fourth Conf. on Probability and Statistics in Atmospheric Sciences, Tallahassee, Amer. Meteor. Soc., 96-101.

Brooks, C. E. P., and S. T. A. Mirrlees, 1930: Irregularities in the annual variation of the temperature of London. Quart. J. Roy. Meteor. Soc., 56, 375-388.

- , and N. Carruthers, 1953: Handbook of Statistical Methods in Meteorology. London, HMSO, 412 pp.

Bryson, R. A., and W. P. Lowry, 1955: Synoptic climatology of the Arizona summer precipitation singularity. Bull. Amer. Meteor. Soc., 36, 329-339.

Conrad, V., 1938: Anomalien and Isanomalen der Sonnenscheindauer in den osterreichischen Alpen. Beih. Jahrb. Zentralanst. Meteor., Vienna.

Craddock, J. M., 1956: The representation of the annual temperature variation over central and northern Europe by a twoterm harmonic form. Quart. J. Roy. Meteor. Soc., 82, 275288.

Fitzpatrick, E. A., D. Hart and H. C. Brookfield, 1966: Rainfall seasonality in the tropical southwest Pacific. Erkunde, 20, 181-194.

Fourier, J. B., 1822: Theorie Analytique de la Chaleur. GauthierVillars et Fils.

Fritz, S., and T. H. MacDonald, 1949: Average solar radiation in the United States. Heat. Vent., 46, 61-64.

Granger, O., 1979: Increasing variability in California precipitation, Ann. Assoc. Amer. Geogr., 69, 533-543.

Hales, J. E., Jr., 1974: Southwestern United States summer monsoon source-Gulf of Mexico or Pacific Ocean? J. Appl. Meteor., 13, 331-342.

Hamon, R. W., L. L. Weiss and W. T. Wilson, 1954: Insolation as an empirical function of daily sunshine duration. Mon. Wea. Rev., 82, 141-146.

Horn, L. H., and R. A. Bryson, 1960: Harmonic analysis of the annual march of precipitation over the United States. Ann. Assoc. Amer. Geogr., 50, 157-171.

,-- and W. P. Lowry, 1957: An objective precipitation cli- matology of the United States. Dept. of Meteor., Sci. Rep. No. 6. University of Wisconsin, 1-34.

Keeping, E. S., 1962: Introduction to Statistical Inference. Princeton, Van Nostrand, 174-273.

Kimball, H. H., 1919: Variations in the total and luminous solar radiation with geographical position in the United States. Mon. Wea. Rev., 47, 769-793.

Kincer, J. B., 1920: Sunshine in the United States. Mon. Wea. Rev., 48, 12-17.

Knapp, C. L., T. L. Stoffel and S. D. Whitaker, 1980: Insolation Data Manual. Solar Energy Res. Inst., 253 pp.

Liu, B. Y. H., and R. C. Jordan, 1960: The interrelationship and characteristic distribution of direct, diffuse and total solar radiation. Sol. Energy, 4, 1-19.

Markham, C. G., 1970: Seasonality of precipitation in the United States. Ann. Assoc. Amer. Geogr., 60, 593-597.

Namais, J., 1972: Influence of Northern Hemisphere general circulation on drought in northeast Brazil. Tellus, 24, 336-342.

Prescott, J. A., 1943: The value of harmonic analysis in climate studies. Aust. J. Sci., 5, 117-119.

Reynolds, G., 1955: Short periods of unseasonal warmth or cold in daily mean maximum temperatures at Bidston. Quart. $J$. Roy. Meteor. Soc., 81, 613-617.

Sabbagh, M. E., and R. A. Bryson, 1962: Aspects of the precipitation climatology of Canada investigated by the method of harmonic analysis. Ann. Assoc. Amer. Geogr., 52, 426-440.

Siegel, S., 1956: Non-parametric Statistics. McGraw-Hill, 312 pp.

von Hann, J., 1917: Die dritteltagige (achtstundige) Liftdruck Schwankung. Meteor. Z., 185.

Wallace, J. M., 1975: Diurnal variations in precipitation and thunderstorm frequency over the conterminous United States. Mon. Wea. Rev., 103, 406-419.

Wexler, H., and J. Namais, 1938: Mean monthly isentropic charts and their relation to departures of summer rainfall. Trans. Amer. Geophys. Union, 19, 164-170.

Whipple, F. J. W., 1917: The significance of harmonic analysis of diurnal variation of pressure. Quart. J. Roy. Meteor. Soc., 43, 282-283.

Willmott, C. J., 1978: P-mode principal components analysis, grouping and precipitation regions in California. Arch. Meteor. Geophys. Bioklim., B26, 277-295. 